\title{
Transcription analysis on response of swine lung to H1N1 swine influenza virus
}

\author{
Yongtao $\mathrm{Li}^{1 \dagger}$, Hongbo Zhou ${ }^{1,2+}$, Zhibin Wen ${ }^{1}$, Shujuan $\mathrm{Wu}^{1}$, Canhui Huang ${ }^{2}$, Guangmin Jia', Huanchun Chen ${ }^{1,2}$ \\ and Meilin $\operatorname{Jin}^{1,2^{*}}$
}

\begin{abstract}
Background: As a mild, highly contagious, respiratory disease, swine influenza always damages the innate immune systems, and increases susceptibility to secondary infections which results in considerable morbidity and mortality in pigs. Nevertheless, the systematical host response of pigs to swine influenza virus infection remains largely unknown. To explore it, a time-course gene expression profiling was performed for comprehensive analysis of the global host response induced by H1N1 swine influenza virus in pigs.

Results: At the early stage of H1N1 swine virus infection, pigs were suffering mild respiratory symptoms and pathological changes. A total of 268 porcine genes showing differential expression (DE) after inoculation were identified to compare with the controls on day 3 post infection (PID) (Fold change $\geq 2, p<0.05$ ). The DE genes were involved in many vital functional classes, mainly including signal transduction, immune response, inflammatory response, cell adhesion and cell-cell signalling. Noticeably, the genes associated with immune and inflammatory response showed highly overexpressed. Through the pathway analysis, the significant pathways mainly concerned with Cell adhesion molecules, Cytokine-cytokine receptor interaction, Toll-like receptor signaling pathway and MAPK signaling pathway, suggesting that the host took different strategies to activate these pathways so as to prevent virus infections at the early stage. However, on PID 7, the predominant function classes of DE genes included signal transduction, metabolism, transcription, development and transport. Furthermore, the most significant pathways switched to PPAR signaling pathway and complement and coagulation cascades, showing that the host might start to repair excessive tissue damage by anti-inflammatory functions. These results on PID 7 demonstrated beneficial turnover for host to prevent excessive inflammatory damage and recover the normal state by activating these clusters of genes.
\end{abstract}

Conclusions: This study shows how the target organ responds to H1N1 swine influenza virus infection in pigs. The observed gene expression profile could help to screen the potential host agents for reducing the prevalence of swine influenza virus and further understand the molecular pathogenesis associated with H1N1 infection in pigs.

\section{Background}

Swine influenza is a respiratory disease in pigs characterized by fever, anorexia, tachypnea, dyspnea and coughing [1]. The causative agent, swine influenza virus (SwIV) contains three key subtypes: H1N1, H3N2 and H1N2 circulating in pigs worldwide [2-5]. In pig flocks, H1N1, as the predominant subtype in clinical surveys or in the

\footnotetext{
*Correspondence: jml8328@126.com

+ Contributed equally

${ }^{1}$ Unit of Animal Infectious Diseases, State Key Laboratory of Agricultural Microbiology, Huazhong Agricultural University. 1 Shizishan Street, Wuhan, Hubei, 430070, P.R. China

Full list of author information is available at the end of the article
}

NCBI Influenza resource, has been further categorized into classical swine H1N1 virus, human-like H1N1 virus and European avian-like H1N1 virus [6-8]. In March 2009, a novel swine-origin H1N1 influenza virus containing a unique combination of gene segments of the North American and Eurasian SwIV lineages has continued to circulate in humans and raised severe concerns about pandemic developments. And the finding indicates the significant role of H1N1-subtype SwIV in the evolution of new viruses with pandemic potential [9].

SwIV replication is mainly restricted to epithelial cells in the respiratory tract with the lung being the major target organ [10]. As a short-lasting disease, swine
C Biomed Central

() 2011 Li et al; licensee BioMed Central Ltd. This is an Open Access article distributed under the terms of the Creative Commons Attribution License (http://creativecommons.org/licenses/by/2.0), which permits unrestricted use, distribution, and reproduction in any medium, provided the original work is properly cited. 
influenza manifests itself with an incubation period of 13 days, then the recovery follows, which is limited to 6 or 7 days after infection [11]. During the acute phase of the disease, SwIV induces an overwhelming and simultaneous pro-inflammatory cytokines in the lungs of infected animals [12]. Recently, researchers have found that after H1N1 SwIV infection, secretion of innate, pro-inflammatory, Th1, Th2, and Th3 cytokines was observed in infected pig lungs, which could be useful indicator for host anti-viral response and SwIV pathogenesis [13]. Among the cytokines, several have been demonstrated to be related with anti-viral functions or tissue damage at the acute stage of SwIV infection, such as IFN-alpha [14], tumour necrosis factor-alpha [15], interleukins [16]. As mentioned above, swine influenza infection has the characteristics of lasting for a short period and quick recovery, which suggests that great number anti-viral molecules, such as IFN-stimulated genes, may play a central role in the infection course, although the detailed information remains to be obtained. Moreover, cytokines are suggested to be able to partly explain why invasive SwIV could cause severe tissue damage by influx of inflammatory cells, which makes animals more susceptible to secondary bacterial infections. In the clinical surveillance, SwIV was a frequent co-infecting agent in swine pneumonia cases [17]. In the previous studies, the experimental dual infection in pigs with a H1N1 SwIV and other pathogens were carried out, and the results determined the contributions of SwIV infection to the enhanced susceptibility to secondary bacteria induced pneumonia $[18,19]$. To date, investigators have mainly concentrated their attention on the implications of swine influenza for public health. However, it is equally worth elucidating basic viral pathogenesis of swine influenza, for swine influenza is one of main immunesuppressive diseases in pig flocks and causes the serious harm to the swine industry. Along this line, it is also indispensable to study the host response against SwIV infection and analyze the potential pathogenesis of SwIV infection.

Moreover, virus infections are generally associated with numerous changes in gene expression of a specific tissue or organ that determines the fate of the ultimate outcome of the infected host. As a high density technology, microarray gene expression profiling has been increasingly used to evaluate the status of gene expressions of pigs after being infected by different pathogens $[20,21]$. In the analysis of the gene regulation patterns, attention has been given to genes related to the key factor in the clinical course and pathology of the disease, particularly when the host was infected with zoonosis, like SwIV [22].

To obtain the sufficient information on host response of H1N1 SwIV infection in pigs, the present study focused on the global genomic analysis of transcriptional responses of pig lungs to $\mathrm{H} 1 \mathrm{~N} 1$ virus infection using Agilent Porcine Oligo Microarray containing more than 42,034 transcripts. The comparison of H1N1 SwIVinfected and mock-infected pig lungs indicated that 268 and 214 DE genes were differently expressed respectively on PID 3 and PID 7 (Fold change $\geq 2$, p $<0.05$ ). As a result, these data would enable us to better understand the underlying pathogenesis of H1N1 SwIV infection in pigs.

\section{Methods}

\section{Animals and viruses}

A total of 30 piglets with high-health status were obtained from a commercial herd and were raised in isolated facilities. To confirm that all piglets were free of swine influenza virus prior to challenge, Hemagglutination Inhibition Test (HI) and Enzyme-linked immunosorbent assay (ELISA) were performed on all pigs' sera and the sera were confirmed negative for the antibodies against $\mathrm{H} 1$ and $\mathrm{H} 3$ swine influenza viruses (unpublished data). The influenza viruses were stored at $-80^{\circ} \mathrm{C}$. The biological properties of swine influenza strains including EID $_{50}$ and TCID $_{50}$ were also determined (unpublished data). The representative of these strains, designated as A/swine/Hubei/101/2009(H1N1) was sequenced and submitted into the Genbank (Accession numbers: CY083005, CY083006, CY083007, CY083008, CY083009, CY083010, CY083011, CY083012).

\section{Virus infection and tissue collection}

All procedures for animal infection and tissue collection were performed according to protocols approved by Biological Studies Animal Care and Use Committee in Hubei Province, PR China. At the age of day 35, 15 pigs were randomly allocated to the non-infected group and another 15 to the infected group. Each piglet in the infected group was intranasaly challenged with $\mathrm{A} /$ swine/ Hubei/101/2009(H1N1) strain at a dose of $10^{7.0} \mathrm{EID}_{50}$ in $2 \mathrm{ml}$ of phosphate buffered saline (PBS) in separate HEPA filtered containment facilities. Each piglet of the non-infected group was treated similarly with an identical volume of PBS as control. Clinical symptoms, including lethargy, anorexia, coughing, hyperpnea or dyspnea, nasal and ocular discharge, and their body temperature were recorded daily. 7 from the infected pigs and 7 from the control pigs were respectively euthanized on PID 3 and 7 by intravenous administration of pentobarbital, and their lungs were removed completely. The percentage of the surface of each pulmonary lobe affected by macroscopic lesions was estimated visually. Virus isolation and $\mathrm{H} 1 \mathrm{~N} 1$ specific quantitative real-time PCR (qRT-PCR) were performed after the pigs were sacrificed on PID 3 and 7. Quantification was achieved 
by relating viral $\mathrm{Ct}$ value to the $\mathrm{Ct}$ value on a standard curve of a measured copy number of a plasmid bearing a 140 bps fragment of the NP gene, amplified by using the following primers: 5-CACTCACCTGATGATTTGGCA-3 (forward) and 5- CAGCAGCTCCAGATCTCCTTG-3 (reverse). Some lungs from both groups were frozen and stored in liquid nitrogen immediately after collection until RNA extraction, and the remaining were fixed in formalin for further histopathology evaluation.

\section{RNA extraction, reverse transcription, RNA labelling and cRNA hybridization Total}

RNA extraction from the lungs prepared from the same lesion, areas of localized infection (with viral mRNA present) was performed using TRIzol by following the standard instructions (Invitrogen, Carlsbad, CA) and a clean-up was carried out using RNeasy columns (Qiagen, Valencia, CA). Both RNA integrity and concentration were evaluated by Agilent 2100 Bioanalyzer by following the manufacturer's instructions (Agilent Technologies, Palo Alto, CA). Reverse transcription of $2 \mu \mathrm{g}$ total RNA and synthesis of Cy3-labelled cRNA with one round of amplification were carried out by a commercial Agilent array service (Shanghaibio, China) following the standard one-cycle protocol according to the manufacturer's instructions. Transcriptional profiles were assessed using Agilent $4 \times 44 \mathrm{~K}$ Porcine Oligo Microarray which contains more than 42,034 transcripts of pig from the database of RefSeq, Unigene and TIGR. Hybridization and scanning of the arrays were carried out according to standard protocols using a G2565BA Scanner (Agilent Technologies, Palo Alto, CA).

\section{Expression microarray analysis and bioinformatics}

Raw data and statistical analyses were performed with Feature Extraction software. Normalization was performed per chip (normalized to 50th percentile) and per gene (normalized to the median) respectively. A statistical analysis of variance (ANOVA) model was applied to the data and the significance was showed by accepting a false discovery rate (FDR) of 0.05. A further cut-off threshold was applied based on a fold change of 2.0 between infected and control pigs. Then all the DE genes were performed for hierarchical cluster (Ver.3.0) and TreeView (Ver.1.1.1) analyses. Genes with significant similarities to the transcripts in $\mathrm{nr}$ database based on BLASTX searches were selected for GO analysis, performed by MAS 3.0 software which was based on DAVID database (CapitalBio, Beijing, China) [23]. Annotation results were obtained by inputting the list of gene symbol as identifier. The Pathway analysis was done using the MAS 3.0 software which was based on the Kyoto Encyclopedia of Genes and Genomes database
(KEGG) (CapitalBio, Beijing, China). The raw and processed data discussed in this publication have been deposited in NCBI's Gene Expression Omnibus and are accessible through GEO Series accession number GSE28871.

\section{qRT-PCR for confirmation}

Microarray results were validated by qRT-PCR using SYBR green-based detection with an ABI PRISM 7500 cycler (Applied Biosystems, Foster City, CA). Total lung RNA $(1 \mu \mathrm{g})$ prepared as described above was reversely transcribed in a $20 \mathrm{ul}$ reaction mixture containing $2 \mathrm{ul}$ avian myeloblastosis virus (AMV) buffer, $50 \mathrm{pM}$ Oligo18T, $0.5 \mathrm{mM}$ dNTPs, $10 \mathrm{U}$ RNase inhibitor and $20 \mathrm{U}$ AMV reverse transcriptase (TAKARA, Japan). All primers were designed using Primer Premier 5.0 software based on the sequences of the corresponding porcine mRNAs in GenBank (Additional file 1). The GAPDH gene was used for expression normalization, using the primers described previously [23]. PCRs were triplicated to guarantee the reproducibility of amplification of the lung cDNA sample from each animal. Changes in gene expression revealed by qRT-PCR were calculated by following the t-test reported previously [24], and a P-value $<0.05$ was considered significant. Reaction specificity was ascertained by performing the Melt procedure at the end of the amplification protocol; and the efficiency of the PCR reaction was $92-99 \%$ for all reactions (slope standard line between-3.3 and-3.6) according to the manufacturer's instructions (Applied Biosystems, Foster City, CA).

\section{Results}

\section{Clinical and Pathological evaluation}

By monitoring the clinical signs of all pigs, it was intriguing to find that most infected pigs just showed mild signs, such as coughing, nasal discharge and dyspnea on PID 1-3 and recovered on PID 5-7. The average body temperature of infected pigs started to increase on PID 1 , peaked around PID 3 with $40.8^{\circ} \mathrm{C}$, and returned to the initial temperature (about $\left.39^{\circ} \mathrm{C}\right)$ until PID $5(\mathrm{P}<0$. 05). As expected, the temperature of the six PBS-mock infected pigs rose slightly on PID 1 and kept stable all the remaining days. To investigate pathological damage to lungs of infected pigs, 7 from the infected pigs and 7 from the control pigs were respectively euthanized on PID 3 and 7 by intravenous administration of pentobarbital, and the macroscopic lesions of lungs tissues were estimated visually (Figure 1A). Then lungs of pigs in each group were fixed by submerging them in $4 \%$ neutral buffered formalin and embedding them in paraffin. Three-micron sections were made before they were stained with hematoxylin and eosin (H\&E). Lung tissues in lesion areas of PID 3 showed dominant pneumonia 


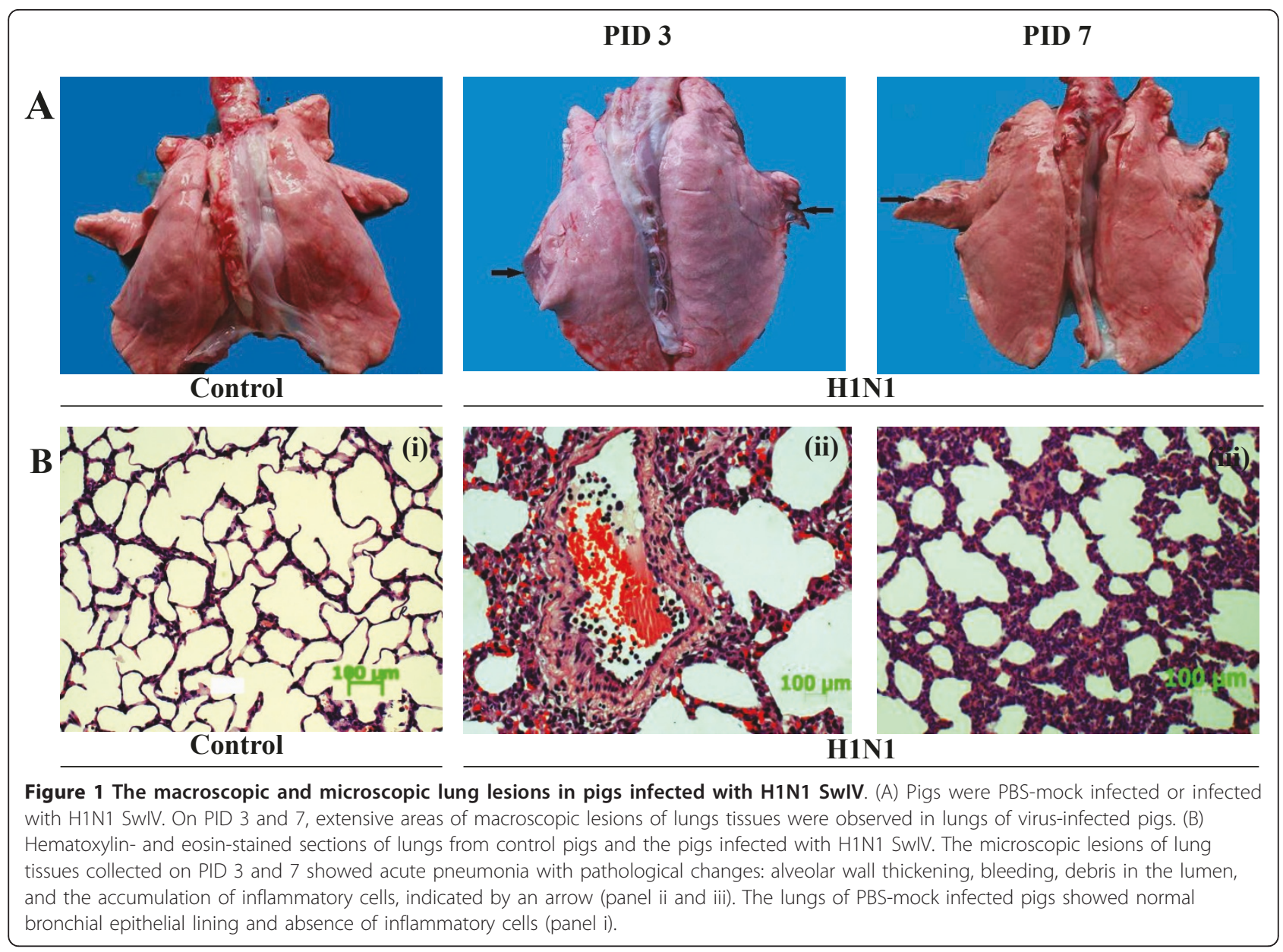

with increased lung elastance, severe edema formation, and pathological responses, such as large amount infiltration of inflammatory cells, alveolar wall thickening and bleeding. The pathological changes of lung tissues on PID 7 were investigated, they just showed slightly alveolar wall thickening with few inflammatory cells, and the PBS-mock infected pigs didn't show lung lesions (Figure 1B).

\section{Virus isolation and confirmation}

The virus could be isolated from lung tissues in all infected pigs on PID 3 and PID 7 but could only be found in nasal swabs of pigs before PID 3. As expected, no virus could be isolated in the controls. To investigate the tissue distribution of virus, samples of heart, liver, spleen, lung, kidney, trachea, tonsil, intestine and serum from pigs were collected on PID 3 and 7 after inoculation, then detected to manifest whether any virus could be isolated from these tissues. Results showed that in most infected pigs, the virus could be isolated only from the trachea and lung. No virus was isolated from heart, liver, intestine, spleen, tonsil or kidney in any infected pigs. The above results were confirmed by qRT-PCR using specific primers for the NP gene (unpublished data). Based on these results, we chose three pigs from each group to perform the following studies.

\section{Gene expression alterations in the lung tissue}

To analyse the genomic expression of SwIV-infected pigs, total RNA was extracted from the infected pig lungs (with viral mRNA present) and from the control pig lungs at the same area. The transcriptome analysis indicated that the detection ratios of all probe sets in the chip representing "expression transcripts" were 75$85 \%$ in different samples, which could exactly meet the quality control standards. The global expression profile of porcine lungs of the infected group was compared with that of the control group. After quantile normalization and statistical analyses, a total of 534 and 467 transcripts at acute and recovery phases were respectively identified to be differentially expressed (Fold change $\geq$ $2, \mathrm{p}<0.05)$. The functions of the DE genes were analysed by MAS 3.0 software. Surprisingly, about half of the transcripts at both time points were not functionally 
annotated, with only a total of 268 genes showing clear functional annotation on PID 3 and 214 genes on PID 7 , and all DE genes were performed for hierarchical cluster (Figure $2 \mathrm{~A}$ and $2 \mathrm{C}$ ). Amongst the $\mathrm{DE}$ genes on PID 3, a set of 160 genes were up-regulated and the rest of 108 genes were down-regulated. The DE genes mainly clustered into functional groups: signal transduction (e.g. TLRs, RLRs), immune response (e.g. GBP1, OAS2), inflammatory response (e.g. CXCL9, CXCL10), cell adhesion (e.g. SELL, SELE), cell-cell signaling (e.g. CCR5, TGF- $\beta 2$ ), biological process (e.g. RETN, APO$B E C 3 A$ ), transport (e.g. Haptocorrin, $A Q P 7)$, oxidation reduction (e.g. DUOX2, ALOX15), interspecies interaction between organisms (e.g. IFIH1, STAT1), response to virus (e.g. MX1, ISG20) and so on (Figure 2B). Particularly, the genes associated with immune and inflammatory response were highly overexpressed among the upregulated genes, which indicated that they may play important roles in host defense response at the early stage of infection (Table 1). Through similar analysis, on
PID 7, it was found that the predominant groups of DE genes contained signal transduction, metabolism, transcription, development and transport, however, the $\mathrm{DE}$ genes related with immune and inflammatory responses became the minority in number (Table 2). The results presented here reflected that it was beneficial for the host to prevent excessive inflammatory damage and recover the normal state by activating these clusters of genes mentioned above (Figure 2D). When comparing the DE genes on PID 3 and 7, only 23 genes were present in the two time points, and they may exert a continuous impact on host at both early and recovery stages (Additional file 2). The complete microarray dataset of the two time points with functional annotations and the changes at expression level is summarized in Supplementary Table (Additional file 3).

\section{Pathway analysis}

To gain insight into the different biological processes of swine influenza infection at the different time points, a

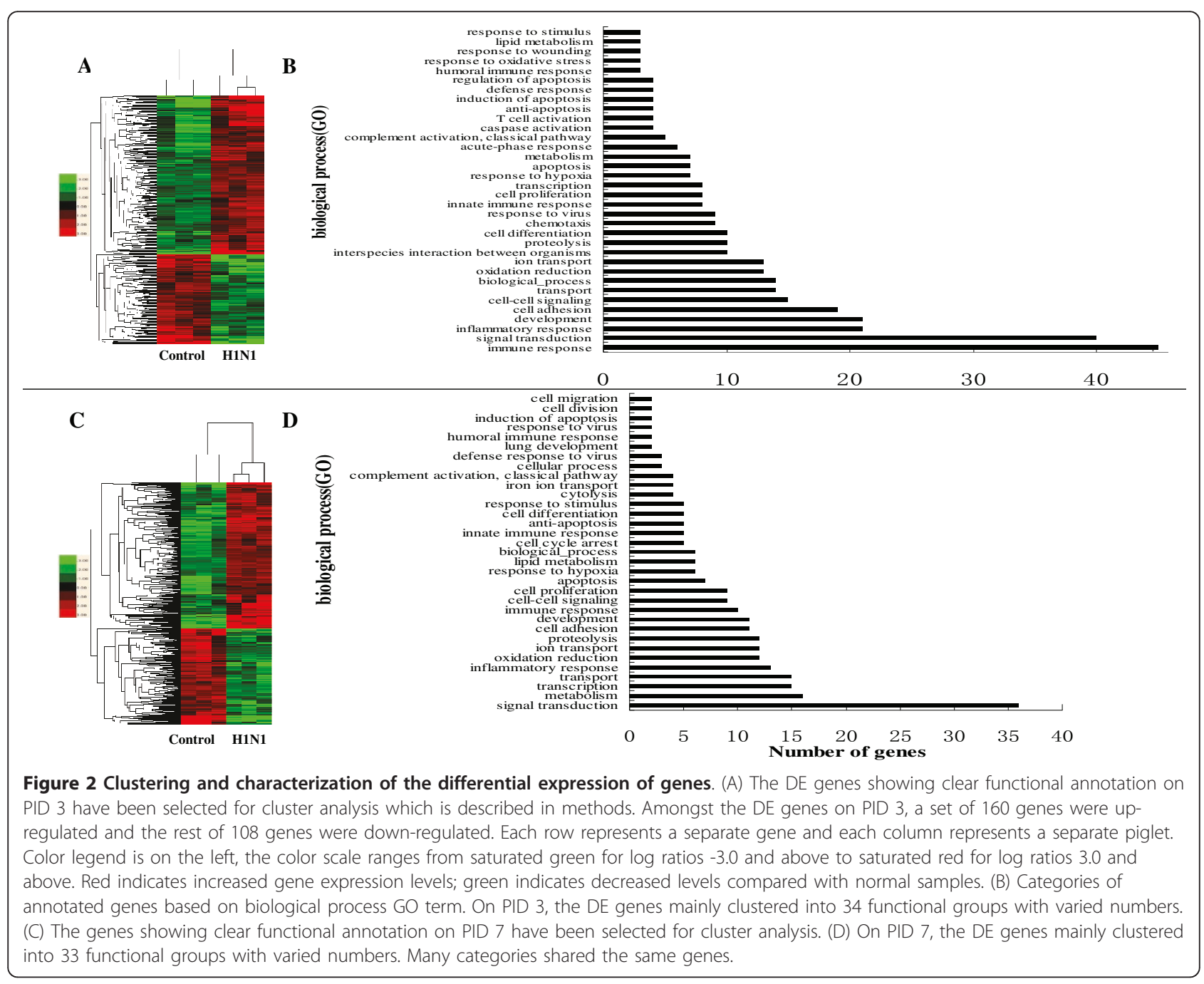


Table 1 The DE genes associated with immune and inflammatory responses on PID 3

\begin{tabular}{|c|c|c|c|c|}
\hline $\begin{array}{l}\text { Functional } \\
\text { classification }\end{array}$ & Gene description & $\begin{array}{l}\text { Gene } \\
\text { symbol }\end{array}$ & $\begin{array}{l}\text { Fold } \\
\text { Change }\end{array}$ & Gen Bank ID \\
\hline & CD45 antigen isoform 3 Fragment & CD45 & 38.62459 & AK230523 \\
\hline & Sus scrofa antibacterial protein & PMAP-23 & 21.70289 & EW419136 \\
\hline & Sus scrofa peptide antibiotic PR39 & PR39 & 13.50724 & NM_214450 \\
\hline immune & Sus scrofa chemokine ligand 26-like mRNA & CCL26 & 8.645769 & NM_001078665 \\
\hline \multirow[t]{46}{*}{ response } & Sus scrofa protegrin 4 NPG4, mRNA & NPG4 & 8.237142 & NM_213863 \\
\hline & Sus scrofa immunoglobulin kappa variable group & IGKV & 6.440473 & CB286369 \\
\hline & Sus scrofa 2'-5'-oligoadenylate synthetase-like mRNA & OASL & 5.803129 & NM_001031790 \\
\hline & Interferon-stimulated gene $20 \mathrm{kDa}$ protein & ISG20 & 5.414398 & NM_001005351.2 \\
\hline & Sus scrofa chemokine $\mathrm{C}-\mathrm{X}-\mathrm{C}$ motif ligand $10 \mathrm{mRNA}$ & CXCL10 & 5.329808 & NM_001008691 \\
\hline & Rep: IL-1 receptor 2-Bos taurus Bovine, partial 98\% & IL1R2 & 5.321422 & NM_001046210.1 \\
\hline & Sus scrofa MHC class II histocompatibility antigen & SLA-DQA1 & 5.232868 & AK230483 \\
\hline & Sus scrofa cathepsin L1-like & CTSL1 & 4.814094 & AK230898 \\
\hline & Sus scrofa interferon regulatory factor 3 (IRF3), mRNA & IRF3 & 4.320395 & NM_213770 \\
\hline & Sus scrofa Fc fragment of IgG, low affinity $1 \mathrm{lb}$, receptor, mRNA & FCGR2B & 3.622257 & NM_001033013 \\
\hline & Sus scrofa CD14 molecule, mRNA & CD14 & 3.544918 & NM_001097445 \\
\hline & Sus scrofa interferon stimulated gene 15 mRNA & ISG15 & 3.45 & EU584557.1 \\
\hline & Sus scrofa lgG heavy chain LOC396781, mRNA & $\lg G$ & 3.438582 & NM_213828 \\
\hline & Sus scrofa interferon-induced protein with tetratricopeptide repeats 1 & $\mathrm{IF|} \mid 56$ & 3.386147 & XM_001928724 \\
\hline & Sus scrofa inducible T-cell co-stimulator ICOS, mRNA & ICOS & 3.353116 & NM_001044546 \\
\hline & Sus scrofa interferon regulatory factor 7 IRF7, mRNA & IRF7 & 3.249327 & NM_001097428 \\
\hline & $\begin{array}{l}\text { Sus scrofa myxovirus influenza virus resistance } 1 \text {, interferon-inducible protein p78 } \\
\qquad M X 1, \text { mRNA }\end{array}$ & MX1 & 3.237013 & NM_214061 \\
\hline & Sus scrofa MHC class I antigen & SLA-2 & 3.187732 & AK231553 \\
\hline & Sus scrofa cytotoxic T-lymphocyte-associated protein 4 CTLA4, mRNA & CTLA4 & 3.184663 & NM_214149 \\
\hline & Sus scrofa DEAD Asp-Glu-Ala-Asp box polypeptide 58 DDX58, mRNA & DDX58 & 3.122048 & NM_213804 \\
\hline & Rep:Tumor necrosis factor receptor superfamily member 17-Homo sapiens & TNFRSF17 & 3.071191 & NM_001192.2 \\
\hline & Sus scrofa CD8a molecule CD8A, mRNA & CD8A & 2.834259 & NM_001001907 \\
\hline & Similar to melanoma cell adhesion molecule & CD146 & -2.819245 & BX915975 \\
\hline & similar to guanylate binding protein 4 & GBP4 & 2.780124 & AK239735 \\
\hline & Sus scrofa guanylate binding protein 1, interferon-inducible, $67 \mathrm{kDa}$ GBP1, mRNA & GBP1 & 2.765026 & NM_001128473 \\
\hline & Sus scrofa ubiquitin specific peptidase 18, mRNA & USP18 & 2.732302 & NM_213826 \\
\hline & Sus scrofa interferon-induced protein with tetratricopeptide repeats 2 mRNA & IFI54 & 2.729199 & AK230663 \\
\hline & mast cell immunoreceptor signal transducer-like & CLNK & 2.704822 & AK237804 \\
\hline & Rep:CD274 molecule CD274, mRNA- Homo sapiens & CD274 & 2.648947 & EW655654 \\
\hline & Sus scrofa CD163 molecule CD163, mRNA & CD163 & 2.633336 & NM_213976 \\
\hline & Sus scrofa interferon-induced protein 44 mRNA & IFI44 & 2.629777 & AK233687 \\
\hline & Sus scrofa interleukin 12A natural killer cell stimulatory factor 1, IL12A, mRNA & IL12A & 2.580563 & NM_213993 \\
\hline & Sus scrofa guanylate binding protein 2 , interferon-inducible GBP2, mRNA & GBP2 & 2.561492 & NM_001128474 \\
\hline & Sus scrofa interferon-induced protein with tetratricopeptide repeats 3 , mRNA & $\mathrm{IF} \mid 60$ & 2.465327 & XM_001928703 \\
\hline & Sus scrofa interferon-induced transmembrane protein 1 & IFITM1 & 2.407903 & AK237820 \\
\hline & Sus scrofa chemokine C-C motif receptor 5 , mRNA & CCR5 & 2.374719 & NM_001001618 \\
\hline & Sus scrofa chemokine $\mathrm{C}-\mathrm{C}$ motif receptor 10 , mRNA & CCR10 & 2.36215 & NM_001044563 \\
\hline & Sus scrofa chemokine $\mathrm{C}-\mathrm{C}$ motif ligand 28 , mRNA & CCL28 & 2.330211 & NM_001024695 \\
\hline & Sus scrofa chemokine C-X-C motif ligand 9 mRNA & CXCL9 & 2.312722 & BP169836 \\
\hline & Sus scrofa transporter 1, ATP-binding cassette, sub-family B MDR/TAP TAP1, mRNA & TAP1 & 2.15635 & NM_001044581 \\
\hline & Sus scrofa Fas ligand TNF superfamily, member 6 , mRNA & FAS & 2.098484 & NM_213806 \\
\hline & Sus scrofa immunoglobulin-associated alpha CD79A, mRNA & CD79A & 2.086904 & NM_001135962 \\
\hline & Sus scrofa interferon induced with helicase $\mathrm{C}$ domain $1 \mathrm{IFIH} 1$, mRNA & $\mathrm{IFIH} 1$ & 2.075703 & NM_001100194 \\
\hline & Sus scrofa aquaporin 9, mRNA & AQP9 & 2.067154 & NM_001112684 \\
\hline & Sus scrofa tumor necrosis factor superfamily member 18 mRNA, partial cds & TNFSF18 & 2.065184 & DQ995649 \\
\hline & Sus scrofa 2'-5'-oligoadenylate synthetase 2, 69/71 kDa OAS2, mRNA & OAS2 & 2.054377 & NM_001031796 \\
\hline
\end{tabular}


Table 1 The DE genes associated with immune and inflammatory responses on PID 3 (Continued)

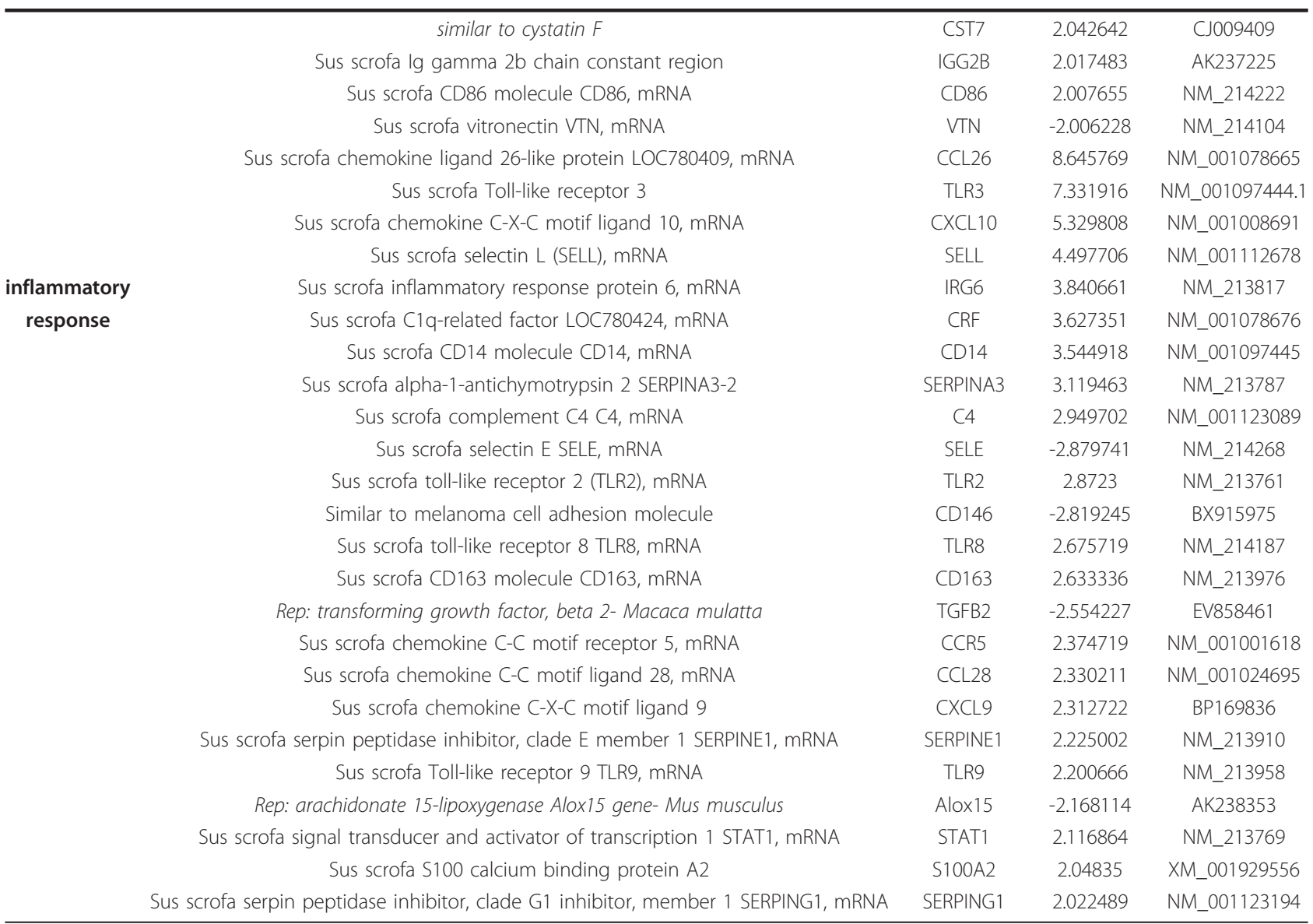

The DE genes associated with immune and inflammatory responses were assigned based on GO term and manual annotation. Manual annotations were listed in italics. Most genes could also be classified into other categories but only immune and inflammatory responses were considered.

pathway analysis was performed on DE genes. We selected most genes for further examination, based on their potential implication in immune and inflammatory response processes. On PID 3, by using the KEGG database, the significant pathways mainly contained Cell adhesion molecules, Cytokine-cytokine receptor interaction, Toll-like receptor signaling pathway and MAPK signaling pathway, which suggested that at the early stage, the host took different strategies to activate immune and inflammatory response so as to prevent from virus infections. However, on PID 7, PPAR signaling pathway and Complement and coagulation cascades became the most significant pathways, indicating that the host start to repair excessive tissue damage by antiinflammatory functions at the recovery stage (Table 3).

\section{Validation of microarray data by qRT-PCR}

In order to get an overall validation of the microarray results, 13 genes with different levels of altered expression (10 up-regulated and 3 down-regulated) were selected for qRT-PCR confirmation, based on their involvement in different functional groups or pathways. Results showed that the altered expression of these 13 genes identified by microarray was consistent with the results of qRT-PCR (Figure 3), although the extent of the changes as measured by the two methods did not match exactly due to the different nature of the procedures (Table 4). What's more, qRT-PCR of 15 representative genes associated with anti-viral immune function were performed including TLRs and interferon-induced genes (ISGs) and found the similar tendency as microarray results (Table 5 ). The data could indicate that the results from the microarray analysis are good indicators of overall changes in gene expression.

\section{Discussion}

Swine influenza is an acute respiratory disease caused by influenza A viruses that circulate among pigs with few or no clinical signs. However, after swine influenza infection, the altering host response predisposes to secondary bacterial infection in pigs through complicated mechanisms. At present, the molecular mechanisms of 
Table 2 The DE genes associated with immune and inflammatory responses on PID 7

\begin{tabular}{|c|c|c|c|c|}
\hline $\begin{array}{c}\text { Functional } \\
\text { classification }\end{array}$ & Gene description & Gene symbol & Fold Change & Gen Bank ID \\
\hline & Rep:CD274 molecule CD274, mRNA- Homo sapiens & CD274 & 2.648947 & EW655654 \\
\hline immune & Sus scrofa complement component C6 & C6 & 2.660923 & NM_001097449 \\
\hline \multirow[t]{13}{*}{ response } & Sus scrofa lymphocyte cytosolic protein 2 & LCP2 & 2.461111 & AK230876 \\
\hline & Rep:Sus scrofa tumor necrosis factor superfamily member $18 \mathrm{mRNA}$ & TNFSF18 & 2.5221772 & DQ995649 \\
\hline & Sus scrofa interleukin 2 receptor, alpha & IL2RA & 3.3108058 & NM_213835 \\
\hline & Sus scrofa C-type lectin domain family 5 , member $A$ & CLEC5A & 4.702034 & NM_213990 \\
\hline & Sus scrofa interferon stimulited exonuclease gene $20 \mathrm{kDa}$ & ISG20 & 2.1768405 & NM_001005351 \\
\hline & Sus scrofa MHC class II DR-alpha (SLA-DRA) & SLA-DRA & 2.0392556 & NM_001113706.1 \\
\hline & Sus scrofa secreted phosphoprotein 1 & SPP1 & 3.411632 & NM_214023 \\
\hline & Sus scrofa lymphocyte-activation gene 3 & LAG3 & 2.0111256 & NM_001105306 \\
\hline & Sus scrofa selectin E & SELE & 9.232597 & NM_214268 \\
\hline & Sus scrofa chemokine ligand 26-like mRNA & CCL26 & 8.645769 & NM_001078665 \\
\hline & Sus scrofa Toll-like receptor 3 & TLR3 & 7.331916 & NM_001097444.1 \\
\hline & Sus scrofa matrix metallopeptidase 25 & MMP25 & 3.32788 & NM_213905 \\
\hline & Sus scrofa toll-like receptor 7 & TLR7 & 3.262197 & NM_001097434 \\
\hline \multirow[t]{8}{*}{ inflammatory response } & Sus scrofa interleukin 13 & IL13 & 2.4685268 & NM_213803 \\
\hline & Sus scrofa sphingosine 1-phosphate receptor 3-like & S1PR3 & 2.293045 & BP173206 \\
\hline & chemokine (C-C motif) ligand 8 & CCL8 & 2.0915823 & NM_001164515.1 \\
\hline & Sus scrofa S100 calcium binding protein A2 & S100A2 & 2.04835 & XM_001929556 \\
\hline & Sus scrofa Toll-like receptor 5 & TLR5 & -2.10299 & NM_001123202 \\
\hline & Rep: transforming growth factor, beta 2- Macaca mulatta & TGFB2 & -2.180843 & EV858461 \\
\hline & Rep: leukocyte cell-derived chemotaxin 2 & LECT2 & -2.381497 & NM_002302.2 \\
\hline & Sus scrofa S100 calcium binding protein A16 & S100A16 & -13.31639 & NM_001190208.1 \\
\hline
\end{tabular}

The DE genes associated with inflammatory response were assigned based on GO term and manual annotation. Manual annotations were listed in italics. Most genes could also be classified into other categories but only immune and inflammatory responses were considered.

host factors involved in pathogenesis and secondary infection have not been clearly established due to the lack of overall information about host response after influenza infection in pigs. The pathogenesis of swine influenza resembles that of human influenza [25]. In humans, many studies have shown that the severe disease associated with influenza infection might arise through different mechanisms, and one important factor is the augmented host response induced by influenza virus [25]. In view of this, a genomic expression analysis was performed to obtain global information of the host response in lungs of infected pigs at different infection stages. While our clinical and pathological findings are in keeping with the findings of other authors, our

Table 3 The key pathways that contain an over-representation of regulated genes in pig lungs after incubation with H1N1 SwIV on PID 3 and 7

\begin{tabular}{cccc}
\hline KEGG pathway(PID 3) & Gene number & KEGG pathway(PID 7) & Gene number \\
\hline Cell adhesion molecules (CAMs) & 17 & PPAR signaling pathway & 8 \\
Cytokine-cytokine receptor interaction & 15 & Focal adhesion & 8 \\
Toll-like receptor signaling pathway & 13 & Cytokine-cytokine receptor interaction & 8 \\
MAPK signaling pathway & 13 & Complement and coagulation cascades & 7 \\
Focal adhesion & 12 & Wht signaling pathway & 6 \\
Complement and coagulation cascades & 10 & Adherens junction & 4 \\
T cell receptor signaling pathway & 8 & ECM-receptor interaction & 4 \\
Antigen processing and presentation & 7 & Toll-like receptor signaling pathway & 4 \\
PPAR signaling pathway & 5 & Cell cycle & 4 \\
ECM-receptor interaction & 5 & Natural killer cell mediated cytotoxicity & 4 \\
Jak-STAT signaling pathway & 4 & Oxidative phosphorylation & 4 \\
B cell receptor signaling pathway & 4 & 4 & 4 \\
\hline
\end{tabular}

At each time-point, the pathway classes were more than the results present in the table. Only these containing relative high gene numbers and low $\mathrm{p}$-Value were chose for analysis. 


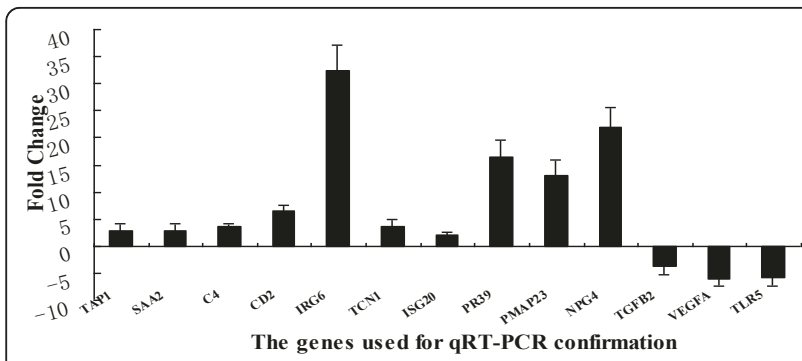

Figure 3 Validation of the microarray data by qRT-PCR analyses. The genes of TAP1, SAA2, C4, CD2, IRG6, TCN1, ISG20, PR39, PMAP23 and NPG4 were up regulated in SwIV infected pigs compared with normal controls; TGFB2, VEGFA, TLR5 were down regulated. Fold change is calculated based on the mean intensity value from 3 pigs by using the comparative $\mathrm{Ct}$ method. Significant levels were analyzed by T-test.

unique immunological data allows for the ability to explain the short-lasting clinical signs and severe pathological changes over the course of illness through immune and inflammatory responses of pigs to H1N1 SwIV.

\section{Anti-viral innate immune response}

The innate immune system functions as the first line of host defense against numerous pathogens. Pattern recognition receptors (PRRs) are a class of innate immune response expressed sensors that provide the host with the ability to detect and respond to virus infection, then trigger a class of anti-viral signaling cascades, ultimately ensuring production of necessary effectors molecules required for virus elimination, such as type-I interferons (IFNs). In this study, we found that

Table 4 An overall validation of microarray data by qRTPCR

\begin{tabular}{cccc}
\hline Gene & GenBank ID & Microarray FC & qRT-PCR FC \\
\hline TAP1 & NM_001044581 & 2.46 & 2.83 \\
SAA2 & CB475095 & 8.42 & 2.86 \\
C4 & CF366280 & 2.95 & 3.53 \\
CD2 & NM_213776.1 & 2.93 & 6.43 \\
IRG6 & NM_213817.1 & 3.84 & 32.50 \\
TCN1 & BX675338 & 7.37 & 3.56 \\
ISG20 & NM_001005351.1 & 5.41 & 2.15 \\
PR39 & NM_214450 & 13.51 & 16.48 \\
PMAP23 & EW419136 & 21.7 & 13.07 \\
NPG4 & NM_213863 & 8.24 & 21.99 \\
TGFB2 & NM_214015.1 & -2.55 & -3.83 \\
VEGFA & EU714324 & -2.42 & -6.20 \\
TLR5 & NM_001123202 & -2.10 & -5.78 \\
\hline
\end{tabular}

Fold changes of gene expression in the porcine lung 3 days following H1N1 SwIV infection compared with the controls. The fold changes were calculated by the formula of $2^{\text {-delta-delta } \mathrm{Ct}}$, data was means \pm SD of triplicate reactions for each gene transcript. The expression level of GAPDH was assayed for normalization during quantitative PCR.
Table 5 A validation of Toll-like receptors and IFNstimulated genes by qRT-PCR

\begin{tabular}{cccc}
\hline Gene & GenBank ID & Microarray FC & qRT-PCR FC \\
\hline TLR2 & NM_213761.1 & 2.87 & 4.61 \\
TLR3 & NM_001097444.1 & 7.33 & 3.42 \\
TLR8 & NM_214187 & 2.68 & 2.44 \\
TLR9 & NM_213958 & 2.20 & 1.64 \\
IRF3 & NM_213770.1 & 4.32 & 6.33 \\
IRF7 & NM_001097428 & 3.25 & 11.1 \\
MX1 & NM_214061 & 3.24 & 10.36 \\
ISG15 & EU584557.1 & 3.45 & 5.21 \\
ISG20 & NM_001005351.1 & 5.41 & 2.15 \\
ISG54 & XM_001928671.2 & 2.73 & 6.27 \\
ISG56 & XM_001928724; & 3.39 & 3.43 \\
ISG60 & XM_001928703 & 2.47 & 5.70 \\
GBP1 & NM_001128473 & 2.78 & 12.0 \\
OASL & NM_001031790 & 5.80 & 2.05 \\
OAS2 & NM_001031796 & 2.05 & 28.80 \\
\hline
\end{tabular}

qRT-PCR results of 4 Toll-like receptors and $11 \mathrm{IFN}$-stimulated genes in the SwIV -infected pigs compared with the controls. Gene expression is depicted as relative expression compared to GAPDH gene expression.

several pattern recognition receptors were overexpressed in the infected pigs on PID 3, including intracellular sensors (MDA5, RIG-I and TLR3,8,9) and extracellular sensors (CD14 and TLR2) with differently increased folds, which was determined by qRT-PCR. With this in mind, we hypothesized that Toll-like receptors (TLRs) and RIG-I like receptors (RLRs) might be activated by SwIV then the receptors triggered the activation of NF- $\kappa$ B and IRF3/7, which cooperated in induction of antiviral type I IFNs [26]. Different TLR family detects distinct microbial pathogen associated molecular patterns (PAMPs) and triggers the activation of specific signaling pathways, leading to induction of interferons [27]. Though interferons were not observed up-regulated on PID 3, we hypothesized that interferons might be induced at the earlier time of infection, which could be indicated by the following enhanced production of ISGs [28]. ISGs are a large family of IFN-signaling and IFN-stimulated immune mediators, which may have a crucial role in antiviral response and host defense $[29,30]$. The present study found that on PID 3, ISGs particularly showed the increase of the expression to a relatively high level in response to $\mathrm{H} 1 \mathrm{~N} 1$ virus infection in pigs, and many showed even higher level, e.g. $O A S L$, OAS2, MX1, IRF7, IRF3, IFIT1, IFIT2, IFIT3, ISG15, ISG20 and ISG44. Several recent microarray results have also highlighted the common involvement of IFNmediated anti-viral responses in the acute phase of influenza infections in other animal models, and illustrated the role of interferons in the first line of defense against virus infections [31]. In addition, there are several functionally less well characterized interferon- 
induced genes, such as INDO, CXCL9, CXCL10, GBP1, GBP2, GBP4, IFITM1 and CD274. CD274 is up-regulated on lymphocytes upon IFN-gamma activation and plays a role in $\mathrm{T}$ cell co-stimulation and apoptosis during viral infections [32]. GBPs belong to the same families of IFN inducible GTPases as Mx1, and human GBP1 and GBP2 have been implicated in the resistance to VSV and ECMV infection [33]. The role of porcine GBPs in the influenza virus replication is in process of our research, but the experiment results achieved so far could imply that GBP1 has a significant anti-viral effect for influenza (unpublished data). The interferon-inducible transmembrane proteins (IFITMs) have recently been discovered to restrict an early replication of influenza A virus and flaviviruses, including dengue virus and West Nile virus [34]. The up-regulation of IFNinducible genes after virus infection suggests that the expressions of these genes may play important roles in host antiviral activities. To further confirm the overrepresentation of antiviral genes, qRT-PCR of 15 representative genes was performed including TLRs and ISGs and the similar tendency as microarray results was observed (Figure 4). It was interesting to note that although the majority of up-regulated genes involved in the anti-viral immune response, three inhibitory genes were also up-regulated, including ISG15, USP18 and ISG56, which had been reported as the negative regulators of the RLRs signaling or IFN signaling [35-37]. This finding indicated that the production of these negativeregulated genes was an equally important factor of the host response which may keep extremely pulmonary response in check and help restore the host to its normal state when the infection is no longer present.

IFNs also stimulate the production of the MHC class I and II proteins which play important roles in the immune response to infections. In humans, $H L A-B$ (major histocompatibility complex (MHC); class I; B) and HLA-DRB1 (MHC; class II; DR beta 1) are involved in antigen presentation and the connection of the innate immune system with the adaptive immune system. In

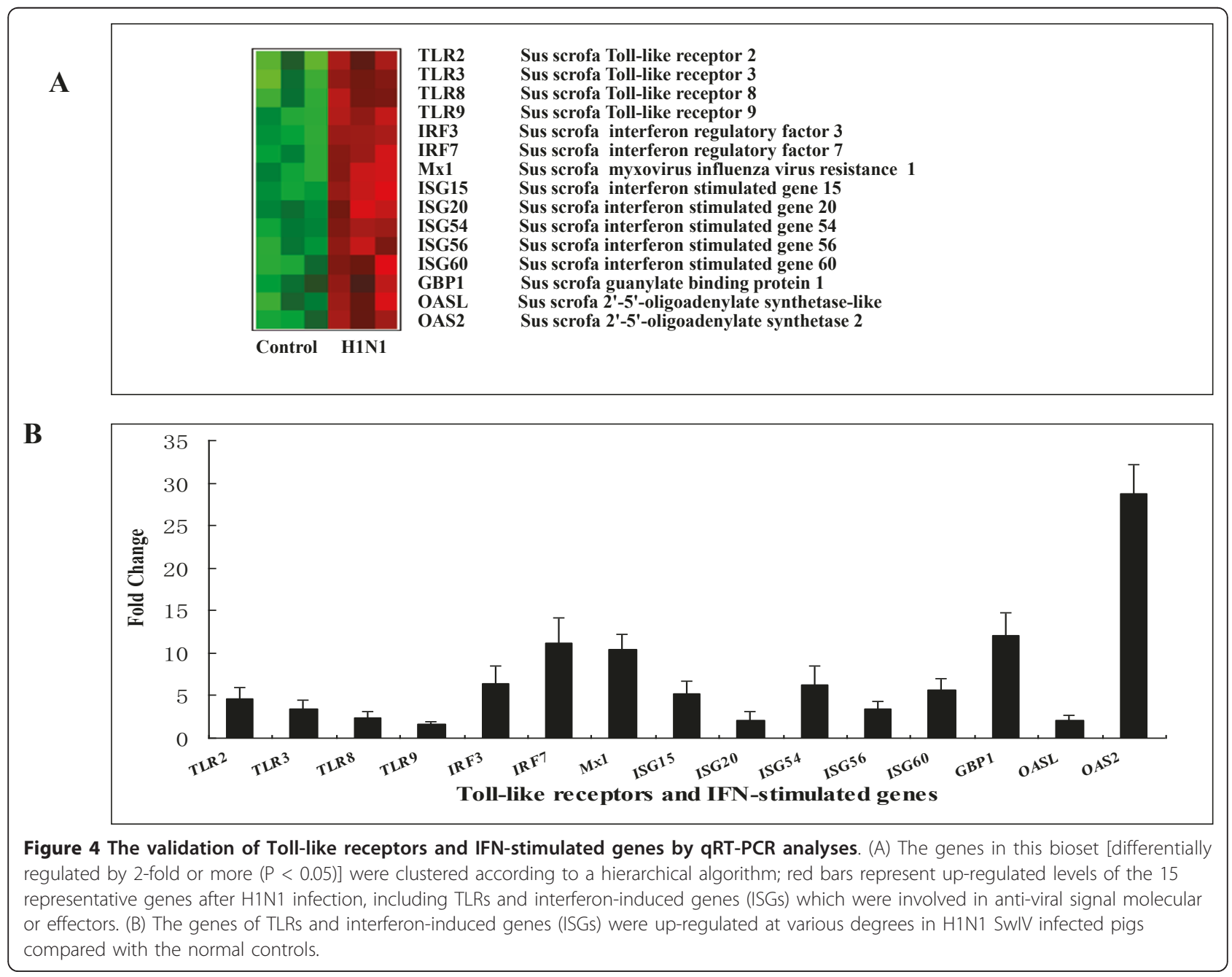


the present study, interestingly, both of the MHC genes, $S L A-B$ and SLA-DQA were up-regulated, at 3.2-fold and 5.2-fold respectively. Previous studies have demonstrated that viruses have evolved mechanisms to inhibit $\mathrm{MHC}$ class I expression by interfering with the function of the MHC class I assembly machinery in the endoplasmic reticulum and by exploiting endoplasmic-reticulumassociated degradation pathways [38]. Different influenza strains demonstrate various abilities in modulating the mRNA expression of MHC class. On the one hand, H3N2 influenza virus could cause the up-regulation of MHC class I mRNA expression levels [39]. On the other hand, the expression of MHC class I did not increase due to the infection of macrophages with a low pathogenic H7N2 AIV [40]. Thus, it can be suggested that H1N1 SwIV may be unable to inhibit MHC genes expression, which should be an important host factor for easily controlling virus.

Besides the above anti-viral agents, another important defense component of an animal innate immune response is constitutive or inducible production of antimicrobial host defense peptides (HDPs). Besides MAPK and JAK/STAT signaling pathways, interaction between virus and TLRs can trigger the $N F-\kappa B$ transcription factor, thus activating down-stream signaling pathway responsible for producing HDPs [41]. In this study, we detected several high-expression antimicrobial peptides on PID 3, such as PMAP23, PR39, CAMP and NPG4 which were all up-regulated with 21.7-fold, 13.5-fold, 8.3-fold and 8.2-fold respectively. A correlation between the acute SwIV infection and the high level of HDP production in pig lungs was demonstrated by qRT-PCR. To evaluate antiviral activity of the HDPs, PMAP23 and NPG4 were chosen to further characterize the function in vitro. The primary results demonstrated that in most cases, either peptides pre-incubation with virus prior to addition to cells, or simultaneous addition to cells in cell culture medium, yielded similar results with regard to inactivation of viral infectivity in a dose-dependent manner (unpublished data). These findings suggest that HDPs contribute to an early host defense against SIV infection which may be the potential antiviral effectors of pigs.

\section{Inflammatory responses}

When successfully overcoming the first barrier of host defense, influenza virus will infect the lung epithelial cells and macrophages then activates the production of proinflammatory cytokines and chemokines through distinct signaling pathways $[42,43]$. Using DNA microarrays, the gene expression patterns that correlate with inflammatory response of virus infection can be identified. Through such approach, it has been reported that different animals (such as primates, ferrets and mice) with influenza infection have been induced extraordinarily high expression of cytokines and chemokines (e.g. CXCL10, CCL2 and CXCL9) [44-46]. In the current report, we found that a large amount of genes involved in inflammatory response were up-regulated at various degrees after H1N1 SwIV infection, such as SERPINA3, CXCL9, CXCL10, CD163, CD14, CCR5, CCL26, C4 and $A L O X 15$. Furthermore, we also found that thirteen genes involved in Toll-like receptors pathway and another thirteen genes in MAPK signaling pathway were regulated, which reflected the up-stream signaling cascades that could lead to secretion of inflammatory cytokines and chemokines. The role of pro-inflammatory cytokines and chemokines in the pathogenesis of $\mathrm{H} 1 \mathrm{~N} 1$ virus infection in mammal remains controversial. For instance, in response to pro-inflammatory cytokines, immune cells migrate toward the areas of infection where they exert host defense functions by phagocytosing cell debris and invading microorganisms, and eventually controlled the infection. However, the overabundant productions of inflammatory responses are responsible for the signs and pathogenesis of influenza infection $[47,48]$. For example, CXCL10 is thought to play a role in the temporal development of innate and adaptive immunity in concert with type I and II IFNs [49]. However, previous studies in vivo have also shown that $C X C L 10$ potentially contributes to lung pathology of $\mathrm{H} 1 \mathrm{~N} 1$ virus infection [50]. In addition, the receptors of chemokines play an important role in site-directed migration and activation of leukocytes. In our studies, CCR5, CCR10 and CXCR6 were slightly upregulated at the early infection. Previous studies have proved that avian $\mathrm{H} 1 \mathrm{~N} 1$ influenza virus could enhance expression of CCR5 in infected adult MDMs [51]. Using knock-down mice model, CCR5 was demonstrated to play a significant role in reducing the mortality rates of mice after influenza virus infection, which indicated that CCR5 significantly affected the course of immune mechanisms as well as the clinical outcome, although in a profound way [52]. In addition, it has been deeply studied that cell adhesion molecules, which can mediate virus-elicited alveolar monocyte accumulation in SwIVinfected pigs, play essential roles in many immune and inflammatory responses [53]. In the current study, through KEGG pathway analysis, we found that cell adhesion molecules (CAMs) pathway was the significant one during the acute virus infection, which contained the families of immunoglobulin superfamily (IGSF21), selectins (SELL, SELE), and others like F11R, CD274, CD2, $C R 2$ and their ligands. Briefly, the above results suggest that the production of inflammatory cytokines and cell adhesion molecules in pigs could not only contribute to the control of virus replication but also elicit significant tissue damage of lung in the context of acute H1N1 virus infection. 
In order to keep homeostasis of development and metabolism, the host must express anti-inflammatory factors to prevent excessive inflammatory damage caused by infection. In this study, we found several genes were regulated after influenza infection which involved in anti-inflammatory functions through PPAR signaling pathway especially on PID 7. The activation of PPAR pathway can play the significant role in antiinflammatory process because they reduce expression of several pro-inflammatory cytokines, chemokines, and cell adhesion molecules [54]. Except for genes of PPAR signaling, we also detected up-regulation of other individual anti-inflammatory factors, such as IL1-RA, IL2RA, HSP4O and HSP70. Interestingly, as the anti-inflammatory mediator, $T G F-\beta 2$ was found to be down-regulated for SwIV infection throughout the whole process, which was demonstrated by qRT-PCR. Previous studies showed that human $\mathrm{H} 1 \mathrm{~N} 1$ virus could induce a persistent elevation of TGF- $\beta 2 \mathrm{mRNA}$ at human pulmonary epithelial cells [55], while highly pathogenic H5N1 virus could cause a down-regulation of TGF- $\beta$ secretion in mice model which resulted in more severe and widespread lesions [56]. Whether the down-regulation of TGF- $\beta$ was caused by swine influenza or responsible for acute lung immunopathology of early infection of swine influenza remains to be further studied. From these analyses, we could propose that the infection course is the balance of pro-inflammatory versus anti-inflammatory factors, and these in common affects clinical outcome of influenza virus infections.

\section{Acute-phase response}

Acute phase proteins (APPs), such as LTF, SAA2 and coagulation factor XIII, were involved in physiologic reactions initiated early in the inflammatory process [57]. Acute phase proteins were also reported as host antiviral factors against virus infection. In response to influenza virus infection, numerous acute phase proteins in plasma, such as CRP, SAA1, and Orosomucoid, increased dramatically in concentration [58,59]. In the present study, we found several genes such as $S E R$ PINA3, MBL2, F2, CD163, SAA2 and lactotransferrin were all up-regulated with 3.12-fold, 2.57-fold, 2.14-fold, 2.63-fold, 8.43-fold and 12.4-fold respectively on PID 3. These up-regulated genes are representative of acute response of host and may help host eliminate the invading viruses. However, it is interesting to note that the genes including Alpha-2-macroglobulin (A2M), Transferrin and Fibronectin were down-regulated on PID 3. $A 2 M$ has been identified as the inhibitor of influenza $\mathrm{A}$ virus in pig serum with virus-neutralizing activity [60]. Recently, using proteomics method, researchers identified $A 2 M$ in the salivary of people infected with swine origin influenza A virus (S-OIV), and explored $A 2 M$ as a novel receptor-targeted inhibitor against S-OIV [61]. The cause and effect of down-regulated expression of these genes associated with acute-phase response need further study.

\section{The expression of the immune cell markers}

Cellular immune responses are critical for the complete clearance of the influenza virus [62]. Pigs infected with $\mathrm{H} 3 \mathrm{~N} 2$ and $\mathrm{H} 1 \mathrm{~N} 1$ viruses have an increased frequency of neutrophils, NK cells, and CD4 and CD8 T cells in the BAL fluid [63]. As pulmonary inflammation after influenza virus infection often involves immune cells infiltration, it raises the question whether the host response occurs primarily in sessile lung cells or could be attributed to infiltrating immune cells. In the current study, several genes as immune cell markers were also detected moderately upregulated, containing some markers associated with monocytes and macrophages (e.g. CD14, CD163) or T lymphocytes (e.g. $C D 2, C D 3 \varepsilon$ and $C D 8 A$ ) on PID 3 [64]. In some cases these CD molecules do show a parallel expression pattern, as expected if the gene expression responses are caused by cellular influx. Recently, some researchers have found that higher frequencies of cytotoxic $\mathrm{T}$ lymphocytes, dendritic cells, activated T cells, and CD4+ and CD8+ T cells could be detected in SwIV-infected pig lungs by flow cytometric analysis [13]. In addition, leukocyte/endothelial cell adhesion molecules are essential mediators of both immune and inflammatory responses, especially implicated in leukocyte recruitment, trafficking and tissue damage [52]. In the current study, some cell adhesion molecules were detected over-expression during the acute virus infection, such as the families of immunoglobulin superfamily (IGSF21), selectins (SELL, SELE), and other molecules like CD274, CR2 and their ligands, which could be considered as the indirect evidences for leukocyte recruitments. Therefore, these suggested that the host immune and inflammatory responses in our study could be partly attributed to immune-related cells influx after virus infection. Other functional classes of DE genes involved in host response might be essentially dependent on gene expression changes in sessile pulmonary cells. Further study is suggested to be focused on the impact of immune cells influx to transcriptional changes of lungs after SwIV infection.

\section{Conclusions}

In this work, we compared host clinical signs and pathology changes between infected pigs with H1N1 SwIV and the controls at the different stages, and subsequently determined 268 DE genes on PID 3 and 214 DE genes on PID 7 respectively, through DNA microarray analysis under the specific criteria. Our data explained that a series of genes involved in host defense responses were activated after the H1N1 SwIV invasion, which 
might be contributors to eliminating virus and severe immunopathology associated with virus infections. The comparison of the overall pattern of antiviral signaling and pro-inflammatory pathways activated by SwIV, it could help to screen the potential host agents for reducing the prevalence of SwIV and further understand the pathogenesis of swine influenza infection in pigs.

\section{Additional material}

\section{Additional file 1: Primers used for qRT-PCR validation. \\ Additional file 2: The overlapping DE genes on PID 3 and 7. \\ Additional file 3: The complete microarray dataset of DE genes on PID 3 and 7 with functional annotations and expression level changes.}

\section{Abbreviations}

SwIV: swine influenza virus; PID: day post infection; DE: differential expression; FC: fold change; GO: Gene Ontology; KEGG: Kyoto Encyclopedia of Genes and Genomes; FDR: false discovery rate; qRT-PCR: quantitative realtime PCR; TLR: Toll-like receptors; HDPs: host defense peptides.

\section{Acknowledgements}

The authors would like to thank Cao Yi for his contribution to animal experiments and Professor Liu Yanxiu for critically reading the manuscript. The study was supported by China National Basic Research Program (China "973" Program 2011CB505004 \& 2010CB534002), National Natural Science Foundation of China (no. 31072154 \& 30800832), and China National Science and Technology Major Projects (no. 2008ZX10004-013 and 2009ZX10004109), the National Transgenic Major Program (2009ZX08009-141B).

\section{Author details}

${ }^{1}$ Unit of Animal Infectious Diseases, State Key Laboratory of Agricultural Microbiology, Huazhong Agricultural University. 1 Shizishan Street, Wuhan, Hubei, 430070, P.R. China. ${ }^{2}$ College of Veterinary Medicine, Huazhong Agricultural University, P.R. China. Shizishan Street, Wuhan, Hubei, 430070, P. R. China.

\section{Authors' contributions}

YTL and HBZ carried out all works in the lab and drafted the manuscript. ZBW, SJW and HCC made substantial contributions to bioinformatics and statistical analysis. $\mathrm{CHH}$ and GMJ participated in the animal challenge experiment. MLJ conceived the study and participated in its coordination and helped to draft the manuscript. All authors read and approved the final manuscript.

\section{Competing interests}

The authors declare that they have no competing interests.

Received: 25 February 2011 Accepted: 8 August 2011

Published: 8 August 2011

\section{References}

1. Van Reeth $\mathrm{K}$, Nauwynck H, Pensaert M: Clinical effects of experimental dual infections with porcine reproductive and respiratory syndrome virus followed by swine influenza virus in conventional and colostrumdeprived pigs. J Vet Med 2001, 48(4):283-292.

2. Brown $\mathrm{H}$, Ludwig $\mathrm{S}$, Olsen CW, Hannoun C, Scholtissek C, Hinshaw VS, Harris PA, McCauley JW, Strong I, Alexander DJ: Antigenic and genetic analyses of H1N1 influenza A viruses from European pigs. J Gen Virol 1997, 78(3):553-562.

3. Gourreau JM, Kaiser C, Valette M, Douglas AR, Labie J, Aymard M: Isolation of two H1N2 influenza viruses from swine in France. Arch Virol 1994, 135(3-4):365-382.
4. Olsen CW: The emergence of novel swine influenza viruses in North America. Virus Res 2002, 85(2):199-210.

5. Richt JA, Lager KM, Janke BH, Woods RD, Webster RG, Webby RJ: Pathogenic and antigenic properties of phylogenetically distinct reassortant $\mathrm{H} 3 \mathrm{~N} 2$ swine influenza viruses cocirculating in the United States. J Clin Microbial 2003, 41(7):3198-3205.

6. Gatherer D: The $2009 \mathrm{H} 1 \mathrm{~N} 1$ influenza outbreak in its historical context. J Clin Virol 2009, 45(3):174-178.

7. Brown $\mathbb{H}$ : Swine influenza virus infection in pigs. Part 1: swine, avian and human influenza viruses.[http://www.pighealth.com/influenza.htm].

8. Brown $\mathbb{H}$ : The epidemiology and evolution of influenza viruses in pigs. Vet Microbial 2000, 74:, 29-46.

9. Novel Swine-Origin Influenza A (H1N1) Virus Investigation Team, Dawood FS, Jain S, Finelli L, Shaw MW, Lindstrom S, Garten RJ, Gubareva LV, Xu X, Bridges CB, Uyeki TM: Emergence of a novel swineorigin influenza $A$ (H1N1) virus in humans. N Engl J Med 2009, 360(25):2605-2615.

10. Olsen CW, Brown I, Easterday BC, Van Reeth K: Swine influenza. In Diseases of swine.. 9 edition. Edited by: Straw BE, Zimmerman JJ, D'Allaire S, Taylor DJ. Ames: lowa State University Press; 2006:469-482.

11. Loving $C L$, Brockmeier SL, Vincent AL, Palmer MV, Sacco RE, Nicholson $T L$ : Influenza virus coinfection with Bordetella bronchiseptica enhances bacterial colonization and host responses exacerbating pulmonary lesions. Microb Pathog 2010, 49(5):237-245.

12. Jo SK, Kim HS, Cho SW, Seo SH: Pathogenesis and inflammatory responses of swine H1N2 influenza viruses in pigs. Virus Res 2007, 129(1):64-70.

13. Khatri M, Dwivedi V, Krakowka S, Manickam C, Ali A, Wang L, Qin Z, Renukaradhya GJ, Lee CW: Swine influenza H1N1 virus induces acute inflammatory immune responses in pig lungs: a potential animal model for human H1N1 influenza virus. J Virol 2010, 84(21):11210-11218.

14. Barbe F, Saelens X, Braeckmans D, Lefevre F, Reeth KV: Role of IFN-alpha during the acute stage of a swine influenza virus infection. Res Vet $\mathrm{SCi}$ 88(1):172-178.

15. Kim B, Ahn KK, Ha Y, Lee YH, Kim D, Lim JH, Kim SH, Kim MY, Cho KD, Lee $\mathrm{BH}$, Chae $\mathrm{C}$ : Association of tumor necrosis factor-alpha with fever and pulmonary lesion score in pigs experimentally infected with swine influenza virus subtype H1N2. J Vet Med Sci 2009, 71(5):611-616.

16. Barbé F, Atanasova K, Van Reeth K: Cytokines and acute phase proteins associated with acute swine influenza infection in pigs. Vet J 2011, 187(1):48-53.

17. Pallares FJ, Halbur PG, Opriessnig T, Sorden SD, Villar D, Janke BH, Yaeger MJ, Larson DJ, Schwartz KJ, Yoon KJ, Hoffman LJ: Porcine circovirus type 2 (PCV-2) coinfections in US field cases of postweaning multisystemic wasting syndrome (PMWS). J Vet Diagn Invest 2002, 14(6):515-519

18. Yazawa S, Okada M, Ono M, Fujii S, Okuda Y, Shibata I, Kida H: Experimental dual infection of pigs with an H1N1 swine influenza virus (A/Sw/Hok/2/81) and Mycoplasma hyopneumoniae. Vet Microbio/ 2004, 98(3-4):221-228.

19. Loving $\mathrm{CL}$, Brockmeier $\mathrm{SL}$, Vincent $\mathrm{AL}$, Palmer MV, Sacco RE, Nicholson $T L$ : Influenza virus coinfection with Bordetella bronchiseptica enhances bacterial colonization and host responses exacerbating pulmonary lesions. Microb Pathog 2010, 49(5):237-245.

20. Shi Z, Sun J, Guo H, Tu C: Genomic expression profiling of peripheral blood leukocytes of pigs infected with highly virulent classical swine fever virus strain Shimen. J Gen Virol 2009, 90(7):1670-1680.

21. Genini S, Delputte PL, Malinverni R, Cecere M, Stella A, Nauwynck HJ, Giuffra E: Genome-wide transcriptional response of primary alveolar macrophages following infection with porcine reproductive and respiratory syndrome virus. J Gen Virol 89(10):2550-2564.

22. Yewdell J, Garcia-Sastre A: Influenza virus still surprises. Curr Opin Microbio 2002, 5(4):414-418

23. Li R, Zhang A, Chen B, Teng L, Wang Y, Chen H, Jin M: Response of swine spleen to Streptococcus suis infection revealed by transcription analysis. BMC Genomics 2010, 11:556.

24. Zhou H, Zhu J, Tu J, Zou W, Hu Y, Yu Z, Yin W, Li Y, Zhang A, Wu Y, Yu Z, Chen $\mathrm{H}$, Jin M: Effect on virulence and pathogenicity of H5N1 influenza A virus through truncations of NS1 elF4GI binding domain. $J$ Infect Dis 2010, 202(9):1338-46 
25. Peiris JS, Cheung CY, Leung CY, Nicholls JM: Innate immune responses to influenza A H5N1: friend or foe? Trends Immunol 2009, 30(12):574-584

26. Yoneyama M, Kikuchi M, Natsukawa T, Shinobu N, Imaizumi T, Miyagishi M, Taira K, Akira S, Fujita T: The RNA helicase RIG-I has an essential function in double-stranded RNA-induced innate antiviral responses. Nature Immunol 2004, 5:730-737

27. Krishnan J, Selvarajoo K, Tsuchiya M, Lee G, Choi S: Toll-like receptor signal transduction. Exp Mol Med 2007, 39(4):421-38.

28. Van Reeth K, Nauwynck H, Pensaert M: Bronchoalveolar interferon-alpha, tumor necrosis factor-alpha, interleukin-1, and inflammation during acute influenza in pigs: a possible model for humans? J Infect Dis 1998, 177(4):1076-1079.

29. Takaoka A, Yanai $\mathrm{H}$ : Interferon signalling network in innate defense. Cellular microbiol 2006, 8(6):907-922.

30. Durbin JE, Fernandez-Sesma A, Lee CK, Rao TD, Frey AB, Moran TM, Vukmanovic S, Garcia-Sastre A, Levy DE: Type I IFN modulates innate and specific antiviral immunity. J Immunol 2000, 164(8):4220-4228.

31. Rowe $T$, Leon AJ, Crevar CJ, Carter DM, Xu L, Ran L, Fang Y, Cameron CM, Cameron MJ, Banner D, Ng DC, Ran R, Weirback HK, Wiley CA, Kelvin DJ, Ross TM: Modeling host responses in ferrets during A/California/07/2009 influenza infection. Virology 401(2):257-265.

32. Muhlbauer M, Fleck M, Schutz C, Weiss T, Froh M, Blank C, Scholmerich J, Hellerbrand C: PD-L1 is induced in hepatocytes by viral infection and by interferon-alpha and -gamma and mediates T cell apoptosis. $J$ Hepatol 2006, 45(4):520-528.

33. Carter CC, Gorbacheva VY, Vestal DJ: Inhibition of VSV and EMCV replication by the interferon-induced GTPase, mGBP-2: differential requirement for wild-type GTP binding domain. Arch Virol 2005, 150(6):1213-1220.

34. Brass AL, Huang IC, Benita Y, John SP, Krishnan MN, Feeley EM, Ryan BJ, Weyer $J$, van der Weyden L, Fikrig E, Adams DJ, Xavier RJ, Farzan M, Elledge SJ: The IFITM proteins mediate cellular resistance to influenza $A$ H1N1 virus, West Nile virus, and dengue virus. Cell 2009, 139(7):1243-1254.

35. Kim M, Hwang S, Imaizumi T, Yoo J: Negative feedback regulation of RIGI-mediated antiviral signaling by interferon-induced ISG15 conjugation. J Virol 2008, 82(3):1474-1483.

36. Li Y, Li C, Xue P, Zhong B, Mao AP, Ran Y, Chen H, Wang YY, Yang F, Shu HB: ISG56 is a negative-feedback regulator of virus-triggered signaling and cellular antiviral response. Proc Natl Acad Sci USA 2009, 106(19):7945-7950.

37. Malakhova OA, Kim KII, LuO J: UBP43 is a novel regulator of interferon signaling independent of its ISG15 isopeptidase activity. EMBO J 2006 25(11):2358-2367.

38. Yewdell JW, Bennink JR: Mechanisms of viral interference with MHC class I antigen processing and presentation. Annu Rev Cell Dev Biol 1999, 15:579-606.

39. Tong HH, Long JP, Li D, DeMaria TF: Alteration of gene expression in human middle ear epithelial cells induced by influenza $A$ virus and its implication for the pathogenesis of otitis media. Microb Pathog 2004, 37(4):193-204

40. Keeler CL Jr, Bliss TW, Lavric M, Maughan MN: A functional genomics approach to the study of avian innate immunity. Cytogenet Genome Res 2007, 117(1-4):139-145.

41. Fritz JH, Ferrero RL, Philpott DJ, Girardin SE: Nod-like proteins in immunity, inflammation and disease. Nat. Immunol 2006, 7:1250.

42. Cheung CY, Poon LL, Lau AS, Luk W, Lau YL, Shortridge KF, Gordon S, Guan $Y$, Peiris JS: Induction of proinflammatory cytokines in human macrophages by influenza A (H5N1) viruses: a mechanism for the unusual severity of human disease? Lancet 2002, 360(9348):1831-1837.

43. Julkunen I, Sareneva T, Pirhonen J, Ronni T, Melen K, Matikainen S: Molecular pathogenesis of influenza A virus infection and virus-induced regulation of cytokine gene expression. Cytokine Growth Factor Rev 2001, 12(2-3):171-180.

44. Baskin CR, Bielefeldt-Ohmann H, Tumpey TM, Sabourin PJ, Long JP, GarciaSastre A, Tolnay AE, Albrecht R, Pyles JA, Olson PH: Early and sustained innate immune response defines pathology and death in nonhuman primates infected by highly pathogenic influenza virus. Proc Natl Acad SCl USA 2009, 106(9):3455-3460.

45. Cameron CM, Cameron MJ, Bermejo-Martin JF, Ran L, Xu L, Turner PV, Ran R, Danesh A, Fang Y, Chan PK, Mytle N, Sullivan TJ, Collins TL,
Johnson MG, Medina JC, Rowe T, Kelvin DJ: Gene expression analysis of host innate immune responses during Lethal H5N1 infection in ferrets. $J$ Virol 2008, 82(22):11308-11317.

46. Rosseau S, Hocke A, Mollenkopf H, Schmeck B, Suttorp N, Kaufmann SH, Zerrahn J: Comparative transcriptional profiling of the lung reveals shared and distinct features of Streptococcus pneumoniae and influenza A virus infection. Immunology 2007, 120(3):380-391.

47. Szretter KJ, Gangappa S, Lu X, Smith C, Shieh WJ, Zaki SR, Sambhara S, Tumpey TM, Katz JM: Role of host cytokine responses in the pathogenesis of avian H5N1 influenza viruses in mice. J Virol 2007, 81(6):2736-2744

48. Jo SK, Kim HS, Cho SW, Seo SH: Pathogenesis and inflammatory responses of swine H1N2 influenza viruses in pigs. Virus Res 2007, 129(1):64-70.

49. Neville LF, Mathiak G, Bagasra O: The immunobiology of interferongamma inducible protein $10 \mathrm{kD}$ (IP-10): a novel, pleiotropic member of the C-X-C chemokine superfamily. Cytokine Growth Factor Rev 1997, 8(3):207-219.

50. Luster AD: Chemokines-chemotactic cytokines that mediate inflammation. N Engl J Med 1998, 338(7):436-445.

51. Zhou J, Law HK, Cheung CY, Ng IH, Peiris JS, Lau YL: Differential expression of chemokines and their receptors in adult and neonatal macrophages infected with human or avian influenza viruses. $J$ Infect Dis 2006, 194(1):61-70.

52. Tracey CDawson, Melinda ABeck, William AKuziel, Fred Henderson, Nobuyo Maeda: Contrasting Affects of CCR5 and CCR2 Deficiency in the Pulmonary Inflammatory Response to Influenza A Virus. Am J Pathol 2000, 156:1951-1959.

53. Herold S, von Wulffen W, Steinmueller M: Alveolar Epithelial Cells Direct Monocyte Transepithelial Migration upon Influenza Virus Infection: Impact of Chemokines and Adhesion Molecules. J Immunol 2006, 177(3):1817-1824.

54. Straus DS, Glass CK: Anti-inflammatory actions of PPAR ligands: new insights on cellular and molecular mechanisms. Trends Immunol 2007, 28(12):551-558.

55. Lam W, Yeung AC, Chu IM, Chan PK: Profiles of cytokine and chemokine gene expression in human pulmonary epithelial cells induced by human and avian influenza viruses. Virol J 2010, 7:344.

56. Dybing JK, Schultz-Cherry S, Swayne DE, Suarez DL, Perdue ML: Distinct pathogenesis of hong kong-origin $\mathrm{H} 5 \mathrm{~N} 1$ viruses in mice compared to that of other highly pathogenic H5 avian influenza viruses. J Virol 2000, 74(3):1443-1450.

57. Baumann H, Gauldie J: The acute phase response. Immunol Today 1994 , 15(2):74-80.

58. Falsey AR, Walsh EE, Francis CW, Looney RJ, Kolassa JE, Hall WJ, Abraham GN: Response of C-reactive protein and serum amyloid A to influenza A infection in older adults. J Infect Dis 2001, 183(7):995-999.

59. Barclay GR, Flewett TH, Keller E, Halsall HB, Spragg SP: Effect of polymerized orosomucoid on some strains of influenza virus. Biochem $J$ 1969, 111(3):353-357.

60. Ryan-Poirier KA, Kawaoka Y: Alpha 2-macroglobulin is the major neutralizing inhibitor of influenza A virus in pig serum. Virology 1993, 193(2):974-976.

61. Chen C, Zhang X, Lo C: The essentiality of alpha-2-macroglobulin in human salivary innate immunity against new H1N1 swine origin influenza A virus. Proteomics 2010, 10(12):2396-2401.

62. Graham MB, Braciale TJ: Resistance to and recovery from lethal influenza virus infection in B lymphocyte-deficient mice. J Exp Med 1997, 186:2063-2068.

63. Heinen PP, de Boer-Luijtze EA, Bianchi AT: Respiratory and systemic humoral and cellular immune responses of pigs to a heterosubtypic influenza A virus infection. J Gen Virol 2001, 82(Pt11):2697-2707.

64. Piriou-Guzylack L, Salmon H: Membrane markers of the immune cells in swine: an update. Vet Res 2008, 39(6):54.

doi:10.1186/1471-2164-12-398

Cite this article as: Li et al:: Transcription analysis on response of swine lung to H1N1 swine influenza virus. BMC Genomics 2011 12:398. 